\title{
Impact of Implementation of Goods and Services Tax on Nifty 50 Index of National Stock Exchange of India
}

\author{
G. P. Girish \\ Department of Finance, ICFAI Business School (IBS), IFHE University, Hyderabad, India \\ Email: gpgirish.ibs@gmail.com
}

How to cite this paper: Girish, G.P. (2019) Impact of Implementation of Goods and Services Tax on Nifty 50 Index of National Stock Exchange of India. Theoretical Economics Letters, 9, 172-179. https://doi.org/10.4236/tel.2019.91014

Received: January 11, 2019

Accepted: January 29, 2019

Published: February 1, 2019

Copyright (อ 2019 by author(s) and Scientific Research Publishing Inc. This work is licensed under the Creative Commons Attribution International License (CC BY 4.0).

http://creativecommons.org/licenses/by/4.0/

\section{c) (i) Open Access}

\begin{abstract}
The main purpose of this study is to investigate the impact of implementation of goods and services tax on national stock exchange (NSE) of India by considering nifty 50 index of NSE India and by applying event study technique. India embarked upon a new era of global practices by embracing and implementing goods and services tax on 1st July 2017 which was considered as the "event" for this study. Nifty 50 index daily data from 12th June 2017 to 21st July 2017 ( $t \pm 14$ days) are used for the study. The result of the study suggests that implementation of GST impacted nifty 50 index of NSE in a positive way resulting in abnormal returns which is statistically significant. The results of the study provide fresh evidences on our understanding about impact of structural changes on stock market in short-run to regulators, potential investors and high net worth individuals, fund managers, hedge funds and policymakers.
\end{abstract}

\section{Keywords}

National Stock Exchange (NSE), Nifty 50, GST, India, CAAR

\section{Introduction}

India embarked upon a new era of global practices by embracing and implementing goods and services tax (GST) on 1st July 2017. After 13 years' post initial thought process and consideration by Kelkar Task Force report related to value added tax and indirect taxes, Goods and Services Tax has been introduced in India [1]. Implementation of Goods and Services Tax is a major structural change and is believed to be a step in the right direction as opined by economists around the world from a long term perspective: what are its impacts in short run 
and how do Indian stock markets react to this? Answering this question makes sense as Stock markets are considered to be barometer of economic activity and parade sentiment of the market players, companies and industry [2].

Owing to federal structure of India, GST has two components, namely, Central GST and State GST and both Centre and State Governments will levy the same across the value chain. For efficacious implementation of GST in India, GST Network has been registered which is not-for-profit and also non-Governmental company offering common IT infrastructure for tax payers, Central and State Governments and all other stakeholders. Inherent advantages of GST implementation include: wider tax base, rationalized tax structure, synchronization of center and state tax administrations and computerization of compliance procedures reducing errors as many as possible [3].

Literature elucidates many studies exploring the impact of structural changes, political effects, dividend proclamations, oil shocks, etc. on stock market [4]. In this study the author investigates the impact of implementation of goods and services tax on national stock exchange of India by considering nifty 50 index and by applying event study technique. The contribution of the paper is from the perspective of broadening our understanding about impacts of structural changes on the stock market in short run to all market participants, regulators, potential investors and high net worth individuals, fund managers, hedge funds and policymakers. The rest of the paper is structured as follows. In Section 2, we review literature and introduce Indian stock market. In Section 3, we accentuate on the data used for our study and the research methodology. In Section 4, we present our empirical findings and conclude our study. In Section 5, we highlight the scope for the future research.

\section{Literature Review and Indian Stock Market}

Literature elucidates many studies exploring the impact of structural changes, political effects, dividend proclamations, oil shocks, etc on stock market [2] [4] [5] [6] [7]. Event study techniques elucidates impact of any particular incident on the returns of stock market by designing a window both pre-event and post-event and computing abnormal returns during the period. The same technique is employed in literature for ascertaining efficiency of stock market as advocated by [4].

As per efficient market hypothesis (EMH), a market is considered to be informationally efficient if a security's price adjusts swiftly and literally accurate to new information. Fama's [7] original formulation of EMH recognized three forms of market efficiency namely weak, semi-strong and strong form of efficiency based on reflection of information in stock's price. EMH has been conceivably one of the most important paradigms in finance which has been expansively researched and yet remains inconclusive even to this day.

National stock exchange of India (NSE) has total market capitalization of US\$2.27 trillion which makes 11th largest stock exchange in the world. nifty 50 index was launched in 1996 by the NSE India. The nifty 50 index is a diversified 
index comprising of 50 stocks which account for 12 sectors of the Indian economy. It's an index which is widely used in the industry for benchmarking by mutual fund portfolios, institutional investors, index-based derivatives as well as index funds. The nifty 50 index represents approximately $62.9 \%$ of free-float market capitalization of all the stocks listed on NSE India (as on 31st March 2017).

Table 1 provides details about year-wise trading value of different market segments in national stock exchange of India (in Rs. Crores). The growth in Equity Futures \& Options segment has been stupendous and is one of the main reasons why NSE figures as the 11th largest stock exchange in the world. Table 2 provides a snapshot of nifty 50 index performance since 2013-14. Volatility in percentage terms has been calculated as standard deviation of Natural Logarithm of returns for the respective month/year. The table gives us an idea of P/E Ratio of nifty 50 stocks from an emerging market like India. Figure 1 highlights daily closing price of nifty 50 index of national stock exchange of India before and after implementation of GST.

Table 1. Year-wise trading value of different market segments in national stock exchange of India (in Rs. Crores).

\begin{tabular}{cccccc}
\hline Segment/Year & $\mathbf{2 0 1 3 - 1 4}$ & $\mathbf{2 0 1 4 - 1 5}$ & $\mathbf{2 0 1 5 - 1 6}$ & $\mathbf{2 0 1 6 - 1 7}$ & 2017-18 \\
\hline Capital Market & $2,808,488$ & $4,329,655$ & $4,236,983$ & $5,055,913$ & $7,234,826$ \\
Equity Futures \& Options & $38,211,408$ & $55,606,453$ & $64,825,834$ & $94,370,302$ & $164,984,859$ \\
Wholesale Debt Market & 851,434 & 772,369 & 569,495 & 682,426 & 517,889 \\
Currency F\&O & $4,012,513$ & $3,023,908$ & $4,501,886$ & $4,857,076$ & $5,028,502$ \\
Interest Rate Futures & 30,173 & 421,558 & 526,425 & 307,809 & 321,208 \\
Total & $\mathbf{4 5 , 9 1 4 , 0 1 7}$ & $\mathbf{6 4 , 1 5 3 , 9 4 3}$ & $\mathbf{7 4 , 6 6 0 , 6 2 3}$ & $\mathbf{1 0 5 , 2 7 3 , 5 2 6}$ & $\mathbf{1 7 8 , 0 8 7 , 2 8 4}$
\end{tabular}

Source: NSE factbook [8].

Table 2. Snapshot of nifty 50 index performance.

\begin{tabular}{ccccccc}
\hline $\begin{array}{c}\text { Month \& } \\
\text { Year }\end{array}$ & Open & High & Low & Close & Volatility (\%) & $\begin{array}{c}\text { Price to } \\
\text { Earnings Ratio }\end{array}$ \\
\hline $2013-14$ & 5697.35 & 6730.05 & 5118.85 & 6704.20 & 1.1 & 18.9 \\
$2014-15$ & 6729.50 & 9119.20 & 6638.55 & 8491.00 & 0.9 & 22.7 \\
$2015-16$ & 8483.70 & 8844.80 & 6825.80 & 7738.40 & 1.1 & 20.9 \\
$2016-17$ & 7718.05 & 9218.40 & 7516.85 & 9173.75 & 0.8 & 23.3 \\
Apr-17 & 9220.60 & 9367.15 & 9075.15 & 9304.05 & 0.5 & 23.6 \\
May-17 & 9339.85 & 9649.60 & 9269.90 & 9621.25 & 0.6 & 24.4 \\
Jun-17 & 9603.55 & 9709.30 & 9448.75 & 9520.90 & 0.3 & 24.2 \\
Jul-17 & 9587.95 & $10,114.85$ & 9543.55 & $10,077.10$ & 0.4 & 25.7 \\
Aug-17 & $10,101.05$ & $10,137.85$ & 9685.55 & 9917.90 & 0.7 & 25.6 \\
Sep-17 & 9937.65 & $10,178.95$ & 9687.55 & 9788.60 & 0.6 & 25.4 \\
\hline
\end{tabular}

Source: National stock exchange of India [8]. 


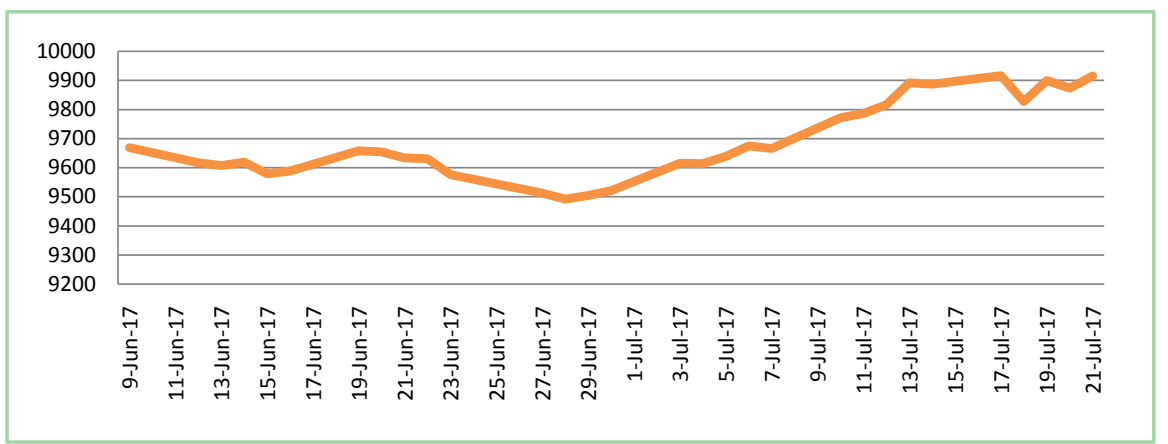

Figure 1. Daily closing price of nifty 50 index of national stock exchange of India before and after implementation of GST. Source: National Stock Exchange of India (NSE).

\section{Data and Methodology}

India embarked upon a new era of global practices by embracing and implementing goods and services tax on 1st July 2017 which is considered as the “event” for this study. Nifty 50 index data from 12th June 2017 to 21 st July 2017 ( $t \pm 14$ days) was collected from the national stock exchange of India website http://www.nseindia.com [8] and the authenticity has been cross-verified from Prowess database.

Fama [7] in efficient market hypothesis advocated that it's not-possible for any market participant to outperform the market (i.e. earn abnormal returns) owing to the fact that all information which is publicly available is already reflected and incorporated into stock prices [9] [10]. Event-study technique is used in literature to investigate semi-strong form of market efficiency. In this study we strive to investigate efficiency of Indian stock market post embracing GST.

We have considered daily closing values of nifty 50 index as given by NSE India. The length of the event window is 28 days ( 14 days before and 14 days after the event).

Returns of nifty 50 index are calculated in the following manner:

$$
R_{t}=\left(P_{t}-P_{t-1}\right) / P_{t-1}
$$

where,

$$
\begin{aligned}
& P_{t}=\text { Closing price of today. } \\
& P_{t-1}=\text { Previous closing price. }
\end{aligned}
$$

Average abnormal return (AAR) is the excess return that is obtained due to occurrence of an event.

$$
\text { Average abnormal return }=\text { Actual return }- \text { Expected return }
$$

After calculating AAR for all the days of the sample window, it is summated to get the cumulative average abnormal return (CAAR). This is designed to find the total average abnormal return made by the nifty 50 index before and after the event.

To empirically investigate the statistical significance of the results obtained, we execute $\mathrm{T}$ Test as follows: 


$$
\begin{gathered}
\mathrm{T} \text { value }(\mathrm{AAR})=\mathrm{AAR} / \mathrm{Standard} \text { deviation of AAR } \\
\mathrm{T} \text { value }(\mathrm{CAAR})=\mathrm{CAAR} / \text { Standard deviation of CAAR }
\end{gathered}
$$

The cumulative average abnormal return (CAAR) is a useful statistical analysis in addition to the average abnormal return (AAR) since it helps us get a sense of the cumulative effect of the abnormal returns predominantly if the influence of the event during the event window is not wholly reflected on the event date itself.

\section{Empirical Findings}

1st July 2017, the date from which GST was implemented in India is considered as the "event" for this study. Daily closing data of nifty 50 index from 12th June 2017 to 21 st July 2017 is used in the study (i.e. $\mathrm{t} \pm 14$ days). Average abnormal returns (AAR) and cumulative average abnormal returns (CAAR) are computed and statistical significance of the obtained results is investigated.

Table 3 shows the average daily return of nifty 50 index in percentage along with daily average abnormal return (AAR), cumulative average abnormal return (CAAR) and also t-value calculated on AAR and CAAR on a day-to-day basis to check the significance of the event of GST implementation. Figure 2 provides details about average abnormal return (AAR) of nifty 50 index of national stock exchange of India before and after implementation of GST. Figure 3 highlights CAAR plot of nifty 50 index of national stock exchange of India before and after implementation of GST. It is quite evident from the plot that the event GST implementation did have an impact on nifty 50 index of NSE India. The null hypothesis that there is no significant difference between the Average Abnormal Returns (AAR) before and after Implementation of GST in nifty 50 index of India is tested using paired t-test and the t-Statistic value obtained is $-2.672 \mathrm{im}$ plying that the null hypothesis is rejected at $10 \%$ significance level. This means that Implementation of GST did impact nifty 50 index of India resulting in abnormal returns which are statistically significant.

The rationale behind calculating abnormal returns is the fact that if there is "no impact" of the event then there shouldn't be any abnormal returns before or after the event. However, in some cases, impact of the event may reflect in the prices after a few days. In such cases cumulative average abnormal return is a better indicator statistically. Table 4 provides statistical test results of cumulative average abnormal return for nifty 50 index of Indian stock exchange due to implementation of GST. The null hypothesis in this case is CAAR is equal to zero. As acknowledged earlier, CAAR is a useful statistical analysis in addition to AAR since it helps us get a sense of the cumulative effect of the abnormal returns predominantly if the influence of the event during the event window is not wholly reflected on the event date itself. The null hypothesis is rejected at $5 \%$ significance level implying that CAAR is not equal to zero which also highlights that implementation of GST impacted nifty 50 index positively and it is statistically significant. 
Table 3. Average abnormal return (AAR) and cumulative average abnormal return (CAAR) for nifty 50 index of Indian stock exchange due to GST.

\begin{tabular}{|c|c|c|c|c|c|}
\hline Day & $\begin{array}{l}\text { Daily Return } \\
\quad \text { (in \%) }\end{array}$ & $\begin{array}{l}\text { Avg. Abnormal } \\
\text { Return (in \%) }\end{array}$ & $\begin{array}{l}\text { Cumulative Avg. } \\
\text { Abnormal Return } \\
\text { (in \%) }\end{array}$ & $\begin{array}{l}\mathrm{t}-\mathrm{V} \text { alue of } \\
\text { CAAR }\end{array}$ & $\begin{array}{c}t-V \text { alue of } \\
\text { AAR }\end{array}$ \\
\hline-14 & -0.536 & -0.610 & -0.610 & -0.762 & -0.776 \\
\hline-13 & -0.099 & -0.173 & -0.783 & -0.978 & -0.220 \\
\hline-12 & 0.117 & 0.043 & -0.740 & -0.924 & 0.055 \\
\hline-11 & -0.417 & -0.491 & -1.231 & -1.538 & -0.625 \\
\hline-10 & 0.104 & 0.030 & -1.200 & -1.500 & 0.039 \\
\hline-9 & 0.725 & 0.651 & -0.550 & -0.687 & 0.828 \\
\hline-8 & -0.042 & -0.116 & -0.666 & -0.831 & -0.148 \\
\hline-7 & -0.206 & -0.280 & -0.946 & -1.181 & -0.356 \\
\hline-6 & -0.037 & -0.111 & -1.057 & -1.320 & -0.142 \\
\hline-5 & -0.572 & -0.646 & -1.703 & -2.127 & -0.821 \\
\hline-4 & -0.664 & -0.738 & -2.440 & -3.048 & -0.939 \\
\hline-3 & -0.212 & -0.286 & -2.726 & -3.405 & -0.364 \\
\hline-2 & 0.135 & 0.061 & -2.665 & -3.329 & 0.078 \\
\hline-1 & 0.177 & 0.103 & -2.562 & -3.200 & 0.131 \\
\hline 0 & 0.988 & 0.914 & 0.914 & 1.063 & 1.163 \\
\hline 1 & -0.018 & -0.092 & 0.823 & 0.957 & -0.117 \\
\hline 2 & 0.253 & 0.179 & 1.001 & 1.164 & 0.227 \\
\hline 3 & 0.383 & 0.309 & 1.311 & 1.524 & 0.394 \\
\hline 4 & -0.090 & -0.164 & 1.146 & 1.333 & -0.209 \\
\hline 5 & 1.089 & 1.015 & 2.161 & 2.513 & 1.291 \\
\hline 6 & 0.154 & 0.080 & 2.241 & 2.606 & 0.101 \\
\hline 7 & 0.307 & 0.233 & 2.474 & 2.877 & 0.297 \\
\hline 8 & 0.770 & 0.696 & 3.170 & 3.686 & 0.886 \\
\hline 9 & -0.054 & -0.128 & 3.042 & 3.537 & -0.163 \\
\hline 10 & 0.299 & 0.225 & 3.267 & 3.799 & 0.287 \\
\hline 11 & -0.896 & -0.970 & 2.298 & 2.672 & -1.233 \\
\hline 12 & 0.737 & 0.663 & 2.961 & 3.443 & 0.844 \\
\hline 13 & -0.266 & -0.340 & 2.621 & 3.048 & -0.432 \\
\hline 14 & 0.425 & 0.351 & 2.972 & 3.456 & 0.446 \\
\hline
\end{tabular}

Source: As computed and compiled by the author.

Table 4. Statistical test results of cumulative average abnormal return (CAAR) for nifty 50 index of Indian stock exchange due to GST.

\begin{tabular}{ccc}
\hline & Before Event & After Event \\
\hline CAAR & -2.562 & 2.972 \\
$t$-Statistic & $-3.083^{* *}$ & $3.339^{* *}$ \\
\hline
\end{tabular}

Note: ${ }^{* *}$ indicates significance at $5 \%$ level. 


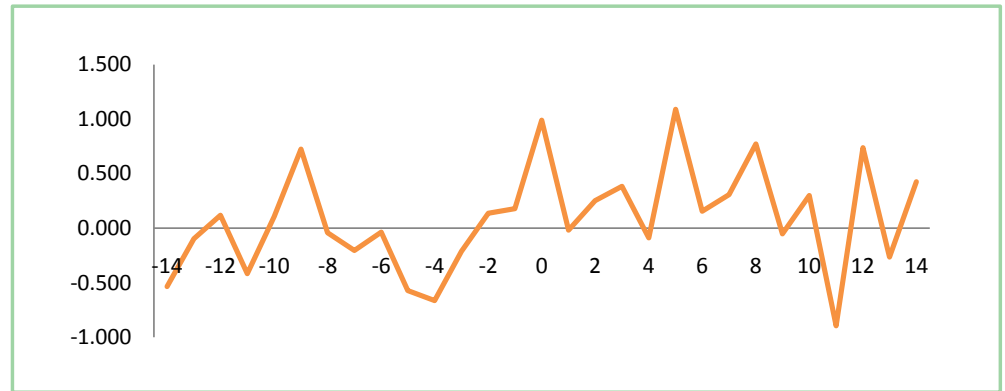

Figure 2. Average abnormal return of nifty 50 index of national stock exchange of India before and after implementation of GST. Source: As computed and compiled by the author.

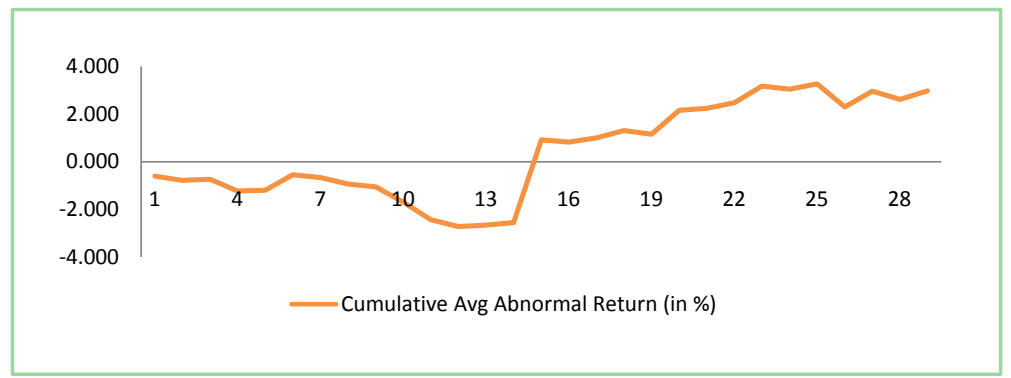

Figure 3. CAAR plot of nifty 50 index of national stock exchange of India before and after implementation of GST. Source: As computed and compiled by the author.

\section{Conclusions}

Implementation of goods and services tax is a major structural change and is believed to be a step in the right direction as opined by economists around the world. Inherent advantages of GST implementation including wider tax base, rationalized tax structure, synchronization of center and state tax administrations and computerization of compliance procedures reducing errors as many as possible far outweigh implementation hiccups. In this study we investigated the impact of implementation of goods and services tax on national stock exchange of India by considering nifty 50 index of NSE and by applying event study technique. The result of the study suggests that implementation of GST impacts nifty 50 index of NSE in a positive way resulting in abnormal returns which is statistically significant. The results of the study seem to suggest that the market participants in India have embraced GST and have reacted positively to its implementation. What it also infers is that there is an opportunity to make short-term money when such events occur in any market by trading on index derivatives namely index futures or index options.

The results of the study provide fresh evidences on our understanding about impacts of structural changes on stock market in short run to regulators, potential investors and high net worth individuals, fund managers, hedge funds and policymakers. Further study can be carried out with larger dataset which is a limitation of this study. Future research can be carried out by analyzing impacts of implementation of GST sector-wise i.e. how GST implementation affects au- 
tomobile sector, manufacturing sector, textile Sector, IT/ITeS sector, agricultural sector, oil and gas sector, and so on. A study of this sort will further elucidate impacts of different GST slabs implemented across different sectors.

\section{Acknowledgements}

This paper was presented in 14th International Conference on Business and Finance (ICBF 2018) which was held in IBS Hyderabad in January, 2019 organized jointly by IBS Hyderabad, IFHE University, India and Gokhale Institute of Politics and Economy, Pune, India. This is a revised and expanded version of the paper.

\section{Conflicts of Interest}

The author declares no conflicts of interest regarding the publication of this paper.

\section{References}

[1] Goods and Services Taxes in India. http://www.gstindia.com/about/

[2] Singhania, K. and Girish, G.P. (2015) Impact of Macroeconomic Events on Shanghai Stock Exchange. Asian Journal of Empirical Research, 6, 64-76. https://econpapers.repec.org/article/asiajoerj/2015_3ap_3a64-76.htm

[3] Ernst and Young Research Report. https://www.ey.com/in/en/services/ey-goods-and-services-tax-gst

[4] Girish, G.P. and Rastogi, N. (2013) Efficiency of S\&P CNX Nifty Index Option of the National Stock Exchange (NSE), India, Using Box Spread Arbitrage Strategy. Gadjah Mada International Journal of Business, 15, 269-285. https://jurnal.ugm.ac.id/gamaijb/article/view/5473

[5] Singh, A.P. (2017) Merge or Acquire-A Strategic Framework. Annals of the University Dunarea de Jos of Galati: Fascicle: XVII, Medicine, 3, 125-139.

[6] Kilian, L. and Park, C. (2009) The Impact of Oil Price Shocks on the U.S. Stock Market. International Economic Review, 50, 1267-1287. https://doi.org/10.1111/j.1468-2354.2009.00568.x

[7] Fama, E.F. (1970) Efficient Capital Markets: A Review of Theory and Empirical Work. The Journal of Finance, 25, 383-417. https://doi.org/10.2307/2325486

[8] National Stock Exchange of India. https://www.nseindia.com/

[9] Fama, E.F. and French, K.R. (2015) A Five-Factor Asset Pricing Model. Journal of Financial Economics, 116, 1-22. https://doi.org/10.1016/j.jfineco.2014.10.010

[10] Fama, E. (1991) Efficient Capital Markets: II. Journal of Finance, 46, 1575-1617. http://www.bu.edu/econ/files/2011/01/Fama2.pdf 